\title{
Insights into pathophysiology of smoke-related cardiovascular disease
}

\section{Approfondimenti nella fisiopatologia delle patologie cardiovascolari correlate al fumo}

\author{
Salvatore De Rosa, Mario Pacileo, Laura Sasso, Vito Di Palma, Paola Maietta, \\ Antonella Paglia, Linda Brevetti, Plinio Cirillo, Massimo Chiariello
}

\begin{abstract}
Insights into pathophysiology of smoke-related cardiovascular disease. S. De Rosa, M. Pacileo, L. Sasso, V. Di Palma, P. Maietta, A. Paglia, L. Brevetti, P. Cirillo, M. Chiariello.

The deleterious effects of cigarette smoke (CS) on cardiovascular morbidity and mortality are well established. Both active and passive smoking represent a major health hazard for both men and women. The great concerns related to the deleterious effects of CS on cardiovascular disease have been translated into various kinds of social interventions and targeted health policies since ever.

The high health impact of cigarette smoking has driven a huge number of researches at the epidemiological, clinical and
\end{abstract}

\begin{abstract}
biological level. Nevertheless, even though many progresses have been made in understanding the mechanisms underlying the high disease burden associated to cigarette smoke, the exact components and the mechanisms by means of which it exerts its effects remain to be completely clarified as yet.

The present paper reviews the main observations on the pathophysiology of smoke-related cardiovascular diseases, providing an up-to-date perspective about one of the main cardiovascular killers of our days.

Keywords: cigarette smoke, cardiovascular disease, atherosclerosis, thrombosis, pathophysiology.
\end{abstract}

Monaldi Arch Chest Dis 2008; 70: 59-67.

Division of Cardiology, University of Naples "Federico II".

Corresponding author: Plinio Cirillo, MD, PhD; Division of Cardiology; University of Naples "Federico II"; Via Sergio Pansini 5; I-80131 Naples - Italy; E-mail address: pcirillo@unina.it

The deleterious effects of cigarette smoke (CS) on cardiovascular morbidity and mortality are widely recognized, as it represents a major health hazard for both men and women. In particular, both active and passive smoke have been associated with significant increase in risk of developing vascular disease and its complications [1-3]. Nevertheless, the challenging question that smokeless tobacco has also been shown to impact CAD risk has raised the interest of physicians worldwide.

The big concerns related to the deleterious effects of CS on cardiovascular disease have been translated into various kinds of social interventions and targeted health policies since ever. In 1987, Europe was the first of WHO's regions to take the initiative of launching a regional action plan on tobacco called for a comprehensive approach: The First European Action Plan on Tobacco 1987-1991 [4]. Still nowadays, all the scientific organizations of the industrialized world are addressing their efforts towards tobacco control $[2,3]$.

Altogether, many progresses have been made in the field of tobacco related disease, both at scientific and social levels. However, although the evidence linking cigarette smoking with cardiovascular risk is clearly established, yet the exact components of cigarette smoke and the mechanisms by means of which it exerts its effects remain to be completely clarified.

\section{Components of cigarette smoke}

It has been assessed that cigarette smoke contains over 5000 chemicals $[5,6]$ in various degrees. Thus, it has been very difficult to identify which component is responsible for the relevant effects exerted by cigarette smoking on atherosclerosis and cardiovascular disease.

However, CS-derived compounds can be catalogued in two different phases: the particulate or tar phase contains all particulate material bigger than $0,1 \mu \mathrm{m}$, that can be trapped by a Cambridge glassfiber filter, while the gas phase represents all the material that passes the filter.

Both phases contain elevated concentrations of reactive oxygen species (ROS) known to exert a wide spectrum of deleterious cellular effects [7]. In addition, the gas phase contains also several stable compounds that have the potential to increase intracellular production of ROS [5], or that have direct effects on cell populations that are actively involved in pathophysiology of cardiovascular diseases such as cells of the vascular wall (endothelial and smooth muscle cells, macrophages) or blood cells (platelets, mononuclear leukocytes).

Among these compounds, unsaturated aldehydes, unsaturated ketones, and nicotine seem to play a detrimental role for human health. Several evidences indicate nicotine as the main active component of ciga- 
Table 1. - Some of the toxic substances found in sigarette smoke

\begin{tabular}{|c|c|}
\hline \multicolumn{2}{|c|}{ Gas Phase } \\
\hline Carbon dioxide & Carbon monoxide \\
\hline Nitrogen oxides & Ammonia \\
\hline Hydrogen cyanide & Hydrazine \\
\hline Formaldehyde & Acetone \\
\hline Acrolein & Acetonitrile \\
\hline Pyridine & 3- Vinylpyridine \\
\hline N-Nitrosodimethylamine & N-Nitrosoethylmethylamine \\
\hline N-Nitrosodiethylamine & N-Nitrosopyrrolidine \\
\hline \multicolumn{2}{|c|}{ Particulate Phase } \\
\hline Nicotine & Toluene \\
\hline Phenol & Catechol \\
\hline Stigmasterol & Naphthalene \\
\hline 1-Methylnaphthalene & 2-Methylnaphthalene \\
\hline Phenanthrene & Benz(a)anthracene \\
\hline Pyrene & Benzo(a)pyrene \\
\hline Quinoline & Methylquinoline \\
\hline Harmane & Norharmane \\
\hline Aniline & o-Toluidine \\
\hline 1-Naphthylamine & 2-Naphthylamine \\
\hline 4-Aminobiphenyl & N'-Nitrosonornicotine \\
\hline NNK & N'-Nitrosoanatabine \\
\hline N'-Nitrosodiathanolamine & \\
\hline
\end{tabular}

Thus, several hypothetical mechanisms of action have been suggested. Some of them have been scientifically well documented, while others still remain speculative.

Nicotine is by far the most studied component of CS. Among the various mechanism proposed for its action, the more investigated and well documented are mediated through direct interaction with a surface receptor. These did not raised much interest at the beginning. In fact, as nicotine was considered just as the "addictive substance" in $\mathrm{CS}$, nicotinic acetylcholine receptors (nAChR) were considered to be responsible only for the psychoactive actions and addiction properties of tobacco smoke [17]. However, several subsequent evidences demonstrated that this receptor was expressed by non neural cells and that nicotine had direct effects on it, giving a big impulse to research focusing on this approach $[18,19]$. In fact, the high density of nAChR on endothelial surface has led to speculations about their pathogenic role in cardiovascular disease [20]. Moreover, deleterious cardiovascular effects of nicotine through stimulation of autonomic nervous system have also been proposed. An intriguing perspective brought about by Yun et al, is that intermittent nicotine exposure may paradox-

rette smoke [8-10]. A similar important role has been described for cotinine, the main nicotine metabolite in humans [11]. In particular, nicotine is known to have a pivotal role in modulating the hemodynamic effects of CS. Indeed, nicotine causes important changes of different cardiac functions such as heart rate, myocardial contractility, cardiac output, stroke volume and coronary blood flow [12, 13]. Moreover, Ball and Turner have observed that nicotine induces vasoconstriction in systemic, cutaneous and coronary vascular beds [14]. In addition, this smoke derivative substance might exert effects on blood lipid profile, promoting hyperlipidemia, with increased VLDL and decreased HDL serum levels. Finally, it has influence on vascular wall causing endothelial injury and intimal hyperplasia, platelet activation with subsequent thrombosis and increases plasma levels of catecholamines, as well as of fibrinogen $[15,16]$.

\section{Mechanisms of action}

Many efforts have been made to explain how cigarette smoke affects cardiovascular system. ically induce reflex adrenergic over-activity and thereby contribute to tobacco related diseases [21]. The described "sympathetic bias" has been suggested to be responsible for many other diseases or conditions associated with CS-related cardiovascular diseases, such as type II diabetes, lipid dysfunction, endothelial dysfunction, vasoconstriction or hypercoagulability [22-24].

Oxydative stress is a well documented mechanism involved in the pathophysiology of cardiovascular disease [25-27]. Interestingly, this phenomenon has also been proposed to be responsible for the cardiovascular effects of cigarette smoking. In fact, CS contains big amounts of short-lived, highly reactive compounds [7]. In addition, other chemical components of CS have been described as able to induce ROS production in various cell populations [5], or from other endogenous sources [28-30]. Many of the deleterious effects exerted by CS on cardiovascular system, such as endothelial dysfunction, vascular inflammation, hypercoagulability, lipid peroxidation and reduced fibrinolysis could be explained by effects of oxidative stress [7, 28-32]. Finally, this hypothesis is strongly supported by the 
Table 2. - Effects of cigarette smoking on atherosclerosis and cardiovascular disease

\begin{tabular}{l}
$\frac{\text { Pathologic effects }}{\text { Vascular intimal injury }}$ \\
Smooth muscle cell proliferation \\
Atherosclerosis \\
Physiologic effects \\
\hline Increase in: \\
- heart rate \\
blood pressure \\
- cardiac output \\
myocardial oxygen and nutrient consumption \\
Lower ventricular fibrilation thresh hold \\
Arrhythmias \\
Impaired coronary artery flow
\end{tabular}

\section{$\underline{\text { Hematologic effects }}$}

Atherosclerosis

Thrombosis

Altered function of:

- prostaglandin, platelets

- fibrinogen

- plasminogen

Reduced oxygen carrying capacity of hemoglobin

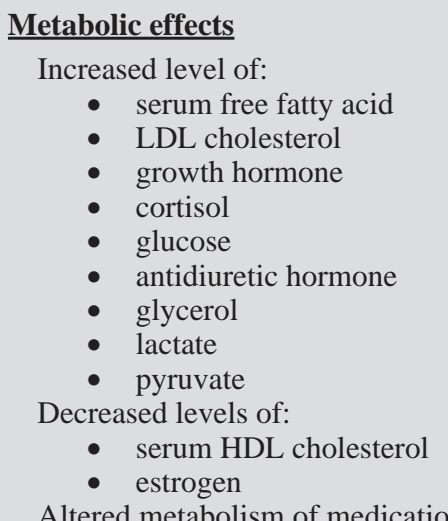

Altered metabolism of medications

observations that drugs with documented antioxidant and/or scavenger effects or able to interfere with the intracellular redox status, might prevent CS effects both in humans and in experimental models [33-36].

Among the huge number of components that have been found in CS, also carbon monoxide (CO) and polycyclic aromatic hydrocarbons have been investigated [37, 38]. However, their role in CS-induced cardiovascular disease is poorly documented and still controversial $[39,40]$.

\section{Effects of cigarette smoke on the vascular wall}

Cigarette smoke has been shown to have several relevant effects on cells of the vascular wall. In particular, CS seems to increase vascular permeability and to activate the pathways of local inflammation [41-44].

\section{Endothelial cells}

Cigarette smoke, and particularly nicotine, exerts powerful effects on endothelial cells, changing the pattern of expression of several genes, some of which are directly correlated with the development of cardiovascular disease [45]. In particular, CS promotes the expression of genes encoding for molecules directly involved in the development of athero-thrombotic disease, such as adhesion molecules and Tissue Factor (TF). Adams et al. have shown an augmented expression of functionally active ICAM-1 on human umbilical vein endothelial cells (HUVECs) stimulated with serum obtained from smokers [35], while Wang et al. reported that nicotine stimulates adhesion molecules expression through an increase of intracellular free $\mathrm{Ca}^{2+}$ and consequent activation of MAP kinases [46]. In addition, Albaugh et al. reported a marked increase in mononuclear leukocytes (MNL) adhesion to HUVECs, after incubation of this vascular cells with nicotine, which was able to induce adhesion molecules on their surface [47]. Finally, our group has demonstrated, in human coronary artery endothelial cells (HCAECs), that nicotine induces expression of functionally active ICAM-1 and VCAM-1 and that this phenomenon occurs through RhoA-mediated activation of the transcription factor NF-kB [48]. These experimental observations obtained in vitro have been confirmed by in vivo studies demonstrating increased expression of adhesion molecules and of pro-thrombotic molecules in atherosclerotic plaques of smokers [49].

Several clinical findings have demonstrated a higher degree of activation of the coagulation pathway in smokers [16, 51]. Indeed, CS promotes thrombotic events stimulating platelet aggregation, as described below, and altering the balance between pro-thrombotic and anti-thrombotic molecules across the vascular wall and in the bloodstream. Experimental data have shown, for example, that HUVEC exposed to smokers' serum show a significant reduction in both basal and stimulated t-PA release, resulting in an alteration of anti thrombotic proprieties of these cells [50]. This result received also further confirmation from the findings of other groups, that observed reduction of plasma levels of t-PA antigen as well as of t-PA activity in smokers $[51,52]$. This reduction of t-PA levels goes with the increased expression of molecules with pro-thrombotic activity such as Tissue Factor (TF). Matetzky et al. have demonstrated, with immunohistochemistry study, increased expression of $\mathrm{TF}$ in atherosclerotic plaques of smokers [49]. This results has been confirmed in vitro by the recent finding of our group that nicotine induces TF expression both in coronary endothelial and in aortic smooth muscle cells [53].

The reduced bioavailability of NO associated with CS also contribute to the pro-thrombotic action of smoke [54]. In particular, thiol-reactive stable compounds of CS can activate NADPH oxidase in endothelium, reducing nitric oxide (NO) bioactivity [55] and Barua et al. observed that smokers' serum reduced NO production both in HUVECs [56] and in HCAECs [57]. In a more recent work, cigarette smoke extract (CSE) was also shown to reduce NO production by endothelial cells [58].

Bernhard et al. recently observed that exposure of endothelial cells to CS caused depolymerization of microtubules and cells contraction. This phe- 
nomenon led to increased vascular permeability, which finally favoured the spreading of inflammatory cells across the vascular wall [59]. Increased of vascular permeability had been also previously described, although without reporting any pathophysiological mechanism, both in vitro [60] and in vivo models [61].

\section{Smooth muscle cells}

Several independent groups have reported various effects of nicotine on vascular smooth muscle cells (VSMCs). Nicotine has mitogenic properties on VSMCs [62]. In Di Luozzo et al. have reported that the mechanism beyond this effect of nicotine is the activation of mitogen-activated protein kinases (MAPK) [63], while Pestana et al. reported the involvement of nicotinic and PDGF receptors in the determinism of this effect [64]. Similar effects of nicotine have been reported in endothelial cells, even though data regarding this phenomenon remain controversial $[65,66]$.

Recent findings have demonstrated that VSMCs express the platelet receptor P2Y12 and that activation of this receptor causes cellular contraction increasing vascular permeability [67]. Interestingly, nicotine seems able to up-regulate expression of this receptor in VSMCs and in other cell populations suggesting a role for this smoke derivative substance in promoting platelet adhesion on vascular wall [68].

\section{Effects of cigarette smoke on leukocytes}

Cigarette smoke induces about a $20-25 \%$ increase in peripheral blood leukocytes and this increase has been described as related to an higher incidence of myocardial infarction [69]. As it has been discussed in the previous paragraph, CS has various effects on the arterial wall that are responsible for increased leukocytes recruitment and trans-endothelial migration. It has been observed that monocytes isolated from smokers present higher than normal expression of CD 11b/CD 18, an integrin which increases adhesiveness of monocytes to cells of the vascular wall [33].

Adhesion of leukocytes to the vascular wall is not just a mechanical process, it rather represents the first step towards trans-endothelial migration and activation of both endothelial and mononuclear cells themselves [70, 71]. It has been reported that cigarette smoke extracts (CSE) induce the expression of different pro-inflammatory cytokines [72-74]. Release of these cytokines could be responsible for augmented trans-endothelial migration of leukocytes and induction of several inflammatory responses [75, 76]. Nevertheless, this mechanism has been questioned after the recent findings, in epithelial cells, macrophages and human peripheral blood mononuclear cells (PBMCs) that CSE could even inhibit the production of some pro.inflammatory cytokines [77-79].

CS has relevant effects on lymphocytes. A recent study has reported that heavy smoke influences gene expression profiles of $\mathrm{T}$ lymphocytes [80]. In addition another study has proposed that one possible mechanism for induction of the chronic inflammatory status related to CS may involve peroxynitrite-induced activation of NF-kB in lymphocytes [81].

Nicotine has been shown to affect also macrophages, a cell population with a key role in atherosclerosis. For example, Lau et al. reported that nicotine induces pro-inflammatory responses in macrophages and in the aorta of LDL receptor /- mice [10]. Macrophages activation by nicotine also results in increased release of TNF- $\alpha$ and IL$1 \beta$, that in turn up-regulate the expression of adhesion molecules on HUVECs and increase adhesion of monocytes [82]. Furthermore, CS-related macrophage activation induces release of major inflammatory mediators suggesting that they could be responsible for the inflammatory processes associated with smoke habitus [83]. Of interest, it has been shown that CS activates PBMCs, and in particular neutrophils, which in turn induce Toll-like receptor-4 mediated cytokine production by human macrophages. These last findings link cigarette smoke to inflammation and innate immunity, bringing about new insights in the pathogenesis of tobacco-related disease [84].

Another interesting phenomenon is that smoking and, more specifically nicotine, are able to promote the immune shift from T helper (Th) 1 to Th 2 [85]. Even though the exact mechanisms by which CS exerts these effects are not definitively understood, it has been recently proposed that intermittent nicotine exposure may lead to receptor desensibilization and paradoxical antagonism of vagal function [21]. Consequently, increased sympathic activity would be responsible for the shift of Th balance to Th2-driven immune response [22].

\section{Effects of cigarette smoke on platelets}

It has been reported that platelets from smokers present an increased aggregation, both spontaneously and after stimulation [86, 87]. In addition, Blache described hyperaggregability in platelets that have been exposed to smoker's serum [88]. In line with these data is the finding that nicotine induces expression of P2Y12, the major platelet receptor that mediates ADP-induced aggregation, not only in endothelial (HCAECs, HUVECs) and smooth muscle cells (HASMCs), but also in human megakaryoblastic cells (MEG-01) [68]. Another mechanism proposed for CS effect on platelet aggregation and thrombosis is a reduced availability of platelet-derived NO, as well as a reduced sensitivity of platelets to exogenous NO $[89,90]$. As a matter of fact, there is an overall reduction of NO bioavailability in plasma of cigarette smokers [58], while also a significant reduction of platelet eNOS mRNA levels has been observed [91].

\section{Cigarette smoke and peripheral arterial disease (PAD)}

Recently, the Edinburgh Artery Study was designed to investigate whether CS-influence on the 
development of peripheral or coronary artery disease might be mediated by other cardiovascular risk factors. In its final report, the authors concluded that the combined effect of smoking on other cardiovascular risk factors could partly explain its influence on peripheral and coronary arterial disease, even though the majority of the effect could not be explained at all, appearing to be due to other mechanisms [92].

Another controversial question is the observation that CS seems to correlate much more strongly with peripheral arterial disease [64] than with coronary artery disease (CAD). Various clinical evidences have strongly correlated smoke habit with PAD. In the Atherosclerosis Risk in Communities (ARIC) Study, smokers had a significantly higher risk of developing PAD over non-smokers [93, 94]. Nevertheless, the stronger association of smoking with PAD than with ischemic heart disease has not been explained yet [95].

\section{Effects of cigarette smoke on neoangiogenesis}

Angiogenesis is a complex and dynamic process, in which different mechanisms acting in combination and whose output reflects the balance between pro- and anti-angiogenetic stimuli. Although various studies have reported toxic effects of nicotine on endothelium, being in favour of nicotine-mediated impairment of angiogenesis $[54,96]$, Heeschen et al. have demonstrated that nicotine promotes the growth of atherosclerotic plaques at least in part stimulating pathological angiogenesis [8]. Another group also reported nicotine-induced promotion of angiogenesis, through cyclooxygenase-2 (COX-2) and vascular endothelial growth factor receptor-2 (VEGFR-2) [97]. On the contrary, Makers et al. have reported an impairment of angiogenesis in female hamsters that have been exposed to cigarette smoke for 30 days [98], while Michaud et al. demonstrated that CS reduces HUVEC migration in response to VEGF [96]. Moreover, an abnormal pattern of blood vessels and altered composition of extracellular matrix in chorioallantoic membranes after exposure to tobacco smoke has also been reported [99]. In contrast with the above cited observations, Eid et al. described a so called "smoker's paradox" because they found a beneficial asymmetric dimethylarginine (ADMA) profile in smokers, responsible of a protective effect against obesity-related endothelial dysfunction [100].

The contrast between findings by independent groups, together with the different experimental settings and the presence of various active compounds in cigarette smoking, make difficult to identify the net effect of smoke on neoangiogenesis. Despite the inexorable difficulties mainly due to the complex physicochemical composition of CS, it appears clear that more accurate determination of the pathophysiologic basis of smoke-related disruption of angiogenetic repair needs rigorous clinical and basic research, specifically designed to complement each other.

\section{Closing remarks}

Due to constant efforts by the scientific community worldwide, the epidemiologic and causal association of smoke with cardiovascular morbidity have been strongly demonstrated [92, 101]. Furthermore, also low tar cigarettes and passive smoke have shown a clear association with cardiovascular disease [102, 103]. Nevertheless, also at the epidemiologic level some questions remain unsolved, as the lack of a clear linear dose effect of CS [92]. Despite the big number of studies available on cigarette smoke and its relation with cardiovascular disease, many steps are still to be moved towards a better understanding of the mechanisms by which CS determines cardiovascular disease.

Many experimental difficulties are directly related with the physical properties of CS. In fact, because there are numerous known and unknown components of CS whose metabolic fate in human body is unknown, an appropriate in vitro model for CSexposure remains to be established.

An intriguing issue regarding the relationship between CS and cardiovascular disease is the strong increase in excess of cardiovascular risk observed along with the interaction of smoke and other classical cardiovascular risk factors $[92,104]$. Although it is clear that CS increases the risk of cardiovascular diseases in subjects with other risk factors, further analytical and metodological observations are needed to correctly understand the chemical and biological synergism between CS and other cardiovascular risk factors.

Among the various mechanisms studied in the available literature, most of the experimental evidences have been produced with nicotine as stimulus. This parallels with the clinical evidence that also low tar cigarettes smoke is associated to similar negative effects [102], as also smokeless tobacco is $[105,106]$. Another property of CS that also has been strongly claimed as significantly responsible for the observed deleterious effects of CS on cardiovascular system is its capacity to increase the levels of oxygen reactive species, even if it remains difficult to verify if this is a direct mechanism or rather it is mediated by established components of CS.

Besides the important achievements reached in the last years, a better understanding of the complex pathophysiology of cigarette smoke and cardiovascular disease is needed. Further research on this topic should be encouraged, particularly aimed at investigating the molecular and cellular mechanisms of CS-induced alterations in cardiovascular physiology.

\section{Riassunto}

Gli effetti deleteri del fumo di sigaretta sulla prevalenza delle patologie cardiovascolari e la mortalità a queste legate sono ormai noti. Inoltre sia il fumo attivo che il cosiddetto "fumo passivo" si correlano ad un rischio elevato di sviluppare malattie cardiovascolari sia negli uomini che nelle donne. Il grande peso del fumo nell'ambito dei fattori di rischio cardiovascolari ha ispirato diverse strategie di intervento sociale soprattutto nell'ultimo decennio. 
L'elevato impatto del fumo di sigaretta sul rischio cardiovascolare, e più in generale sulla salute, ha determinato la conduzione di innumerevoli ricerche, tanto epidemiologiche quanto cliniche e biologiche. Tuttavia, nonostante gli evidenti progressi raggiunti, numerosi interrogativi restano ancora aperti. In particolare, non vi sono chiare evidenze su quali siano i componenti del fumo di sigarette maggiormente e direttamente responsabili delle patologie correlate, così come manca un modello universalmente accettato circa i meccanismi patogenetici coinvolti.

Il presente articolo rappresenta una revisione delle principali osservazioni disponibili in letteratura sulla fisiopatologia delle malattie cardiovascolari correlate al fumo di sigaretta, offrendo una prospettiva aggiornata sulla comprensione dei meccanismi responsabili dell'azione di una delle prime cause di morte al mondo.

\section{LIST OF ABBREVIATIONS}

$\begin{array}{ll}\text { CS: } & \text { cigarette smoke } \\ \text { CAD: } & \text { coronary artery disease } \\ \text { WHO: } & \text { World Health Organization } \\ \text { ROS: } & \text { reactive oxygen species } \\ \text { VLDL: } & \text { very low density lipopriteins } \\ \text { HDL: } & \text { low density lipoproteins } \\ \text { nAChR: } & \text { nicotinic acetylcholine receptor } \\ \text { TF: } & \text { tissue factor } \\ \text { ICAM-1: } & \text { intercellular adhesion molecule 1 } \\ \text { HUVEC: } & \text { human umbilical vein endothelial cell } \\ \text { MAP Kinase } & \text { MAPK): mitogen-activated protein kinase } \\ \text { MNL: } & \text { mononuclear leukocytes } \\ \text { VCAM-1: } & \text { vascular cell adhesion molecule 1 } \\ \text { NF-kB: } & \text { nuclear factor kappa-B } \\ \text { t-PA: } & \text { tissue plasminogen activator } \\ \text { NO: } & \text { nitric oxide } \\ \text { NADPH: } & \text { nicotinamide adenine dinucleotide phosphate } \\ \text { CSE: } & \text { cigarette smoke extract } \\ \text { VSMC: } & \text { vascular smooth muscle cell } \\ \text { PDGF: } & \text { platelet-derived growth factor } \\ \text { PBMC: } & \text { peripheral blood mononuclear cell } \\ \text { LDL: } & \text { low density lipoprotein } \\ \text { TNF- } \alpha: & \text { tumor necrosis factor alpha } \\ \text { IL-1 } \beta: & \text { interleukin 1beta } \\ \text { Th: } & \text { T helper } \\ \text { ADP: } & \text { adenodine diphosphate } \\ \text { MEG-01: } & \text { line of human megakaryoblastic cells } \\ \text { eNOS: } & \text { endothelial nitric oxide synthase } \\ \text { mRNA: } & \text { messenger ribonucleic acid } \\ \text { PAD: } & \text { peripheral arterial disease } \\ \text { ARIC: } & \text { acronym of the study "Atherosclerosis Risk in } \\ & \text { Communities" } \\ \text { COX-2: } & \text { cyclooxygenase-2 } \\ \text { VEGFR-2: } & \text { vascular endothelial growth factor receptor-2 } \\ \text { VEGF: } & \text { vascular endothelial growth factor } \\ \text { ADMA: } & \text { asymmetric dimethylarginine } \\ & \\ & \end{array}$

\section{References}

1. Ockene IS, Miller NH. Cigarette Smoking, Cardiovascular Disease, and Stroke: A Statement for Healthcare Professionals From the American Heart Association. Circulation 1997 96: 3243-3247.

2. Venn A, Britton J. Exposure to Secondhand Smoke and Biomarkers of Cardiovascular Disease Risk in NeverSmoking Adults. Circulation 2007; 115: 990-995.
3. Raupach T, Schafer K, Konstantinides S, Andreas S. Secondhand smoke as an acute threat for the cardiovascular system: a change in paradigm. Eur Heart J 2006; 27: 386-392.

4. Europe, W.R.O.f. Resolution EUR/RC37/R9. In W.R.O.f. Europe, editor World Health Organization. 1987.

5. Stedman RL. The chemical composition of tobacco and tobacco smoke. Chem Rev 1968; 68: 153-207.

6. Villablanca AC, McDonald JM, Rutledge JC. Smoking and cardiovascular disease. Clin Chest Med 2000; 21 : 159-172.

7. Pryor WA, Stone K. Oxidants in cigarette smoke. Radicals, hydrogen peroxide, peroxynitrate, and peroxynitrite. Ann N Y Acad Sci 1993; 686: 12-27.

8. Heeschen C, Jang JJ, Weis M, et al. Nicotine stimulates angiogenesis and promotes tumor growth and atherosclerosis. Nat Med 2001; 7: 833-839.

9. Kilaru S, Frangos SG, Chen AH, et al. Nicotine: a review of its role in atherosclerosis. Journal of the American College of Surgeons 2001; 193: 538-546.

10. Lau PP, Li L, Merched AJ, Zhang AL, Ko KWS, Chan L. Nicotine Induces Proinflammatory Responses in Macrophages and the Aorta Leading to Acceleration of Atherosclerosis in Low-Density Lipoprotein Receptor-/Mice. Arterioscler Thromb Vasc Biol 2006; 26: 143-149.

11. Carty CS, Soloway PD, Kayastha S, et al. Nicotine and cotinine stimulate secretion of basic fibroblast growth factor and affect expression of matrix metalloproteinases in cultured human smooth muscle cells. Journal of Vascular Surgery 1996; 24: 927-935.

12. Aronow W, Dendinger J, Rokaw S. Heart rate and carbon monoxide level after smoking high-, low-, and non-nicotine cigarettes. A study in male patients with angina pectoris. Ann Intern Med 1971; 74: 697-702.

13. Tachmes L, Fernandez RJ, Sackner MA. Hemodynamic effects of smoking cigarettes of high and low nicotine content. Chest 1978; 74: 243-246.

14. Ball K, Turner R. Smoking and the Heart. The basis for action. Lancet 1974; 2: 822-826.

15. Kershbaum A, Bellet S, Dickstein ER, Feinberg LJ. Effect of Cigarette Smoking and Nicotine on Serum Free Fatty Acids: Based on a Study in the Human Subject and the Experimental Animal. Circ Res 1961; 9: 631-638.

16. Hawkins RI. Smoking, platelets and thrombosis. Nature 1972; 236: 450-452.

17. Pontieri FE, Tanda G, Orzi F, Chiara GD. Effects of nicotine on the nucleus accumbens and similarity to those of addictive drugs. Nature 1996; 382: 255-257.

18. Macklin KD, Maus ADJ, Pereira EFR, Albuquerque EX, Conti-Fine BM. Human Vascular Endothelial Cells Express Functional Nicotinic Acetylcholine Receptors. J Pharmacol Exp Ther 1998; 287: 435-439.

19. Villablanca AC. Nicotine stimulates DNA synthesis and proliferation in vascular endothelial cells in vitro. $J$ Appl Physiol 1998; 84: 2089-2098.

20. Conti-Fine BM, Navaneetham D, Lei S, Maus ADJ. Neuronal nicotinic receptors in non-neuronal cells: new mediators of tobacco toxicity? European Journal of Pharmacology 2000; 393: 279-294.

21. Yun AJ, Bazar KA, Lee PY, Gerber A, Daniel SM. The smoking gun: many conditions associated with tobacco exposure may be attributable to paradoxical compensatory autonomic responses to nicotine. Medical Hypotheses 2005; 64: 1073-1079.

22. Yun JA, Lee PY, Bazar KA. Many diseases may reflect dysfunctions of autonomic balance attributable to evolutionary displacement. Medical Hypotheses 2004; 62: 847-851.

23. Manzella D, Paolisso G. Cardiac autonomic activity and Type II diabetes mellitus. Clin Sci 2005; 108: 93-99.

24. Yun AJ, Lee PY, Bazar KA. Can thromboembolism be the result, rather than the inciting cause, of acute vascular events such as stroke, pulmonary embolism, mesenteric 
ischemia, and venous thrombosis?: a maladaptation of the prehistoric trauma response. Medical Hypotheses 2005; 64: 706-716.

25. Nedeljkovic ZS, Gokce N, Loscalzo J. Mechanisms of oxidative stress and vascular dysfunction. Postgrad Med $J$ 2003; 79: 195-200.

26. Golino P, Ragni M, Cirillo P, et al. Effects of tissue factor induced by oxygen free radicals on coronary flow during reperfusion. Nat Med 1996; 2: 35-40.

27. Kojda G, Harrison D. Interactions between NO and reactive oxygen species: pathophysiological importance in atherosclerosis, hypertension, diabetes and heart failure. Cardiovascular Research 1999; 43: 562-571.

28. Guthikonda S, Sinkey C, Barenz T, Haynes WG. Xanthine Oxidase Inhibition Reverses Endothelial Dysfunction in Heavy Smokers. Circulation 2003; 107: 416-421.

29. Heitzer T, Brockhoff C, Mayer B, et al. Tetrahydrobiopterin Improves Endothelium-Dependent Vasodilation in Chronic Smokers: Evidence for a Dysfunctional Nitric Oxide Synthase. Circ Res 2000; 86: e36-41.

30. Ambrosio G, Zweier JL, Duilio C, et al. Evidence that mitochondrial respiration is a source of potentially toxic oxygen free radicals in intact rabbit hearts subjected to ischemia and reflow. J Biol Chem 1993; 268: 18532-18541.

31. Powell JT. Vascular damage from smoking: disease mechanisms at the arterial wall. Vascular Medicine 1998; 3: 21-28.

32. Kayyali US, Budhiraja R, Pennella CM, et al. Upregulation of xanthine oxidase by tobacco smoke condensate in pulmonary endothelial cells. Toxicology and Applied Pharmacology 2003; 188: 59-68.

33. Weber C, Erl W, Weber K, Weber PC. Increased Adhesiveness of Isolated Monocytes to Endothelium Is Prevented by Vitamin C Intake in Smokers. Circulation 1996; 93: 1488-1492.

34. Stadler N, Eggermann J, Voo S, Kranz A, Waltenberger J. Smoking-Induced Monocyte Dysfunction Is Reversed by Vitamin C Supplementation In Vivo. Arterioscler Thromb Vasc Biol 2007; 27: 120-126.

35. Adams MR, Jessup W, Celermajer DS. Cigarette smoking is associated with increased human monocyte adhesion to endothelial cells: reversibility with oral L-arginine but not vitamin C. J Am Coll Cardiol 1997; 29: 491-497.

36. Fennessy FM, Moneley DS, Wang JH, Kelly CJ, Bouchier-Hayes DJ. Taurine and Vitamin C Modify Monocyte and Endothelial Dysfunction in Young Smokers. Circulation 2003; 107: 410-415.

37. Kjeldsen K, Thomsen HK, Astrup P. Effects of Carbon Monoxide on Myocardium: Ultrastructural Changes in Rabbits After Moderate, Chronic Exposure. Circ Res 1974; 34: 339-348.

38. Penn A, Snyder C. Arteriosclerotic plaque development is 'promoted' by polynuclear aromatic hydrocarbons. Carcinogenesis 1988; 9: 2185-2189.

39. Penn A, Currie J, Snyder C. Inhalation of carbon monoxide does not accelerate arteriosclerosis in cockerels. $\mathrm{Eu}$ ropean Journal of Pharmacology: Environmental Toxicology and Pharmacology 1992; 228: 155-164.

40. Zevin S, Saunders S, Gourlay SG, Jacob P, Benowitz NL. Cardiovascular effects of carbon monoxide and cigarette smoking. Journal of the American College of Cardiology 2001; 38: 1633-1638.

41. Barbieri SS, Weksler BB. Tobacco smoke cooperates with interleukin-1\{beta\} to alter $\{$ beta $\}$-catenin trafficking in vascular endothelium resulting in increased permeability and induction of cyclooxygenase- 2 expression in vitro and in vivo. FASEB J 2007; 21: 1831-1843.

42. Hawkins BT, Egleton RD, Davis TP. Modulation of cerebral microvascular permeability by endothelial nicotinic acetylcholine receptors. Am J Physiol Heart Circ Physiol 2005; 289: H212-219.

43. Hawkins BT, Abbruscato TJ, Egleton RD, et al. Nicotine increases in vivo blood-brain barrier permeability and al- ters cerebral microvascular tight junction protein distribution. Brain Research 2004; 1027: 48-58.

44. Pittilo RM, Mackie IJ, Rowles PM, Machin SJ, Woolf N. Effects of cigarette smoking on the ultrastructure of rat thoracic aorta and its ability to produce prostacyclin. Thromb Haemost 1982; 48: 173-176.

45. Zhang S, Day I, Ye S. Nicotine induced changes in gene expression by human coronary artery endothelial cells. Atherosclerosis 2001; 154: 277-283.

46. Wang Y, Wang Z, Zhou Y, et al. Nicotine stimulates adhesion molecular expression via calcium influx and mitogen-activated protein kinases in human endothelial cells. International Journal of Biochemistry and Cell Biology 2006; 38: 170-182.

47. Albaugh G, Bellavance E, Strande L, Heinburger S, Hewitt $\mathrm{CW}$, Alexander JB. Nicotine induces mononuclear leukocyte adhesion and expression of adhesion molecules, VCAM and ICAM, in endothelial cells in vitro. Ann Vasc Surg 2004; 18: 302-307.

48. Cirillo P, Pacileo M, De Rosa S, et al. HMG-CoA Reductase Inhibitors Reduce Nicotine-Induced Expression of Cellular Adhesion Molecules in Cultured Human Coronary Endothelial Cells. J Vasc Res 2007; 44: 460-470.

49. Matetzky S, Tani S, Kangavari S, et al. Smoking Increases Tissue Factor Expression in Atherosclerotic Plaques: Implications for Plaque Thrombogenicity. Circulation 2000; 102: 602-604.

50. Barua RS, Ambrose JA, Saha DC, Eales-Reynolds L-J. Smoking Is Associated With Altered Endothelial-Derived Fibrinolytic and Antithrombotic Factors: An In Vitro Demonstration. Circulation 2002; 106: 905-908.

51. Newby DE, Wright RA, Labinjoh C, et al. Endothelial Dysfunction, Impaired Endogenous Fibrinolysis, and Cigarette Smoking: A Mechanism for Arterial Thrombosis and Myocardial Infarction. Circulation 1999; 99: 1411-1415.

52. Pretorius M, Rosenbaum DA, Lefebvre J, Vaughan DE, Brown NJ. Smoking Impairs Bradykinin-Stimulated t-PA Release. Hypertension 2002; 39: 767-771.

53. Cirillo P, De Rosa S, Pacileo M, et al. Nicotine induces tissue factor expression in cultured endothelial and smooth muscle cells. Journal of Thrombosis and Haemostasis 2006; 4: 453-458.

54. Zhang W-Z, Venardos K, Chin-Dusting J, Kaye DM. Adverse Effects of Cigarette Smoke on NO Bioavailability: Role of Arginine Metabolism and Oxidative Stress. Hypertension 2006; 48: 278-285.

55. Jaimes EA, DeMaster EG, Tian R-X, Raij L. Stable Compounds of Cigarette Smoke Induce Endothelial Superoxide Anion Production via NADPH Oxidase Activation. Arterioscler Thromb Vasc Biol 2004; 24: 1031-1036.

56. Barua RS, Ambrose JA, Eales-Reynolds L-J, DeVoe MC, Zervas JG, Saha D.C. Dysfunctional Endothelial Nitric Oxide Biosynthesis in Healthy Smokers With Impaired Endothelium-Dependent Vasodilatation. Circulation 2001; 104: 1905-1910.

57. Barua RS, Ambrose JA, Srivastava S, DeVoe MC, EalesReynolds L-J. Reactive Oxygen Species Are Involved in Smoking-Induced Dysfunction of Nitric Oxide Biosynthesis and Upregulation of Endothelial Nitric Oxide Synthase: An In Vitro Demonstration in Human Coronary Artery Endothelial Cells. Circulation 2003; 107: 2342-2347.

58. Zhang W-Z, Venardos K, Chin-Dusting J, Kaye DM. Response to Cigarettes and ADMA: The Smoke Hasn't Cleared Yet. Hypertension 2006; 48: E21-.

59. Bernhard D, Csordas A, Henderson B, Rossmann A, Kind M, Wick G. Cigarette smoke metal-catalyzed protein oxidation leads to vascular endothelial cell contraction by depolymerization of microtubules. FASEB $J$ 2005; 19: 1096-1107.

60. Holden WE, Maier JM, Malinow MR. Cigarette smoke extract increases albumin flux across pulmonary endothelium in vitro. $J$ Appl Physiol 1989; 66: 443-449. 
61. Allen DR, Browse NL, Rutt DL, Butler L, Fletcher C. The effect of cigarette smoke, nicotine, and carbon monoxide on the permeability of the arterial wall. Journal of vascular surgery: official publication, the Society for Vascular Surgery [and] International Society for Cardiovascular Surgery, North American Chapter 1987; 7: 139-152.

62. Cucina A, Sapienza P, Corvino V, et al. Nicotine-induced smooth muscle cell proliferation is mediated through bFGF and TGF-[beta]1. Surgery 2000; 127: 316-322.

63. Di Luozzo G, Pradhan S, Dhadwal AK, Chen A, Ueno H, Sumpio BE. Nicotine induces mitogen-activated protein kinase dependent vascular smooth muscle cell migration. Atherosclerosis 2005; 178: 271-277.

64. Pestana IA, Vazquez-Padron RI, Aitouche A, Pham SM. Nicotinic and PDGF-receptor function are essential for nicotine-stimulated mitogenesis in human vascular smooth muscle cells. Journal of Cellular Biochemistry 2005; 96: 986-995.

65. Kuhlmann CRW, Scharbrodt W, Schaefer CA, et al. Discordant effects of nicotine on endothelial cell proliferation, migration, and the inward rectifier potassium current. Journal of Molecular and Cellular Cardiology 2005; 38: 315-322.

66. Dasgupta P, Rastogi S, Pillai S, et al. Nicotine induces cell proliferation by $\{$ beta $\}$-arrestin-mediated activation of Src and Rb-Raf-1 pathways. J Clin Invest 2006; 116 : 2208-2217.

67. Wihlborg A-K, Wang L, Braun OO, et al. ADP Receptor P2Y12 Is Expressed in Vascular Smooth Muscle Cells and Stimulates Contraction in Human Blood Vessels. Arterioscler Thromb Vasc Biol 2004; 24: 1810-1815.

68. Shanker G, Kontos J, Eckman D, Wesley-Farrington D, Sane D. Nicotine upregulates the expression of P2Y12 on vascular cells and megakaryoblasts. Journal of Thrombosis and Thrombolysis 2006; 22: 213-220.

69. Smith CJ, Fischer TH. Particulate and vapor phase constituents of cigarette mainstream smoke and risk of myocardial infarction. Atherosclerosis 2001; 158: 257-267.

70. Allingham MJ, van Buul JD, Burridge K. ICAM-1-Mediated, Src- and Pyk2-Dependent Vascular Endothelial Cadherin Tyrosine Phosphorylation Is Required for Leukocyte Transendothelial Migration. J Immunol 2007; 179: 4053-4064.

71. Vega-Ostertag ME, Ferrara DE, Romay-Penabad Z, et al. Role of p38 mitogen-activated protein kinase in antiphospholipid antibody-mediated thrombosis and endothelial cell activation. Journal of Thrombosis and Haemostasis 2007; 5: 1828-1834.

72. Reynolds PR, Cosio MG, Hoidal JR. Cigarette Smoke-Induced Egr-1 Upregulates Proinflammatory Cytokines in Pulmonary Epithelial Cells. Am J Respir Cell Mol Biol 2006; 35: 314-319.

73. Li C-J, Ning W, Matthay MA, Feghali-Bostwick CA, Choi AMK. MAPK pathway mediates EGR-1-HSP70dependent cigarette smoke-induced chemokine production. Am J Physiol Lung Cell Mol Physiol 2007; 292: L1297-1303.

74. Orosz Z, Csiszar A, Labinskyy N, et al. Cigarette smokeinduced proinflammatory alterations in the endothelial phenotype: role of $\mathrm{NAD}(\mathrm{P}) \mathrm{H}$ oxidase activation. $\mathrm{Am} J$ Physiol Heart Circ Physiol 2007; 292: H130-139.

75. Rao RM, Yang L, Garcia-Cardena G, Luscinskas FW. Endothelial-Dependent Mechanisms of Leukocyte Recruitment to the Vascular Wall. Circ Res 2007; 101: 234247.

76. Middleton RK, Lloyd GM, Bown MJ, Cooper NJ, London NJ, Sayers RD. The pro-inflammatory and chemotactic cytokine microenvironment of the abdominal aortic aneurysm wall: A protein array study. Journal of Vascular Surgery 2007; 45: 574-580.

77. Gaschler GJ, Zavitz CCJ, Bauer CMT, et al. Cigarette Smoke Exposure Attenuates Cytokine Production by
Mouse Alveolar Macrophages. Am J Respir Cell Mol Biol 2007; 2007-0053OC.

78. Ouyang Y, Virasch N, Hao P, et al. Suppression of human IL-1 [beta], IL-2, IFN-[gamma], and TNF-[alpha] production by cigarette smoke extracts. Journal of Allergy and Clinical Immunology 2000; 106: 280-287.

79. Witherden IR, Vanden Bon EJ, Goldstraw P, Ratcliffe C, Pastorino U, Tetley TD. Primary Human Alveolar Type II Epithelial Cell Chemokine Release: Effects of Cigarette Smoke and Neutrophil Elastase. Am J Respir Cell Mol Biol 2004; 30: 500-509.

80. Büttner P, Mosig S, Funke H. Gene expression profiles of $\mathrm{T}$ lymphocytes are sensitive to the influence of heavy smoking: a pilot study. Immunogenetics 2007; 59: 37-43.

81. Bar-Shai M, Hasnis E, Wiener-Megnazi Z, Reznik AZ. The role of reactive nitrogen species and cigarette smoke in activation of transcription factor NF-kB and implication to inflammatory processes. Journal of Physiology and Pharmacology 2006; 57: 39-44.

82. Wang Y, Wang L, Ai X, et al. Nicotine could augment adhesion molecule expression in human endothelial cells through macrophages secreting TNF-[alpha], IL-1[beta]. International Immunopharmacology 2004; 4: 1675-1686.

83. Facchinetti F, Amadei F, Geppetti P, et al. \{alpha\}, \{beta $\}$-unsaturated Aldehydes in Cigarette Smoke Release Inflammatory Mediators from Human Macrophages. Am J Respir Cell Mol Biol 2007; 2007-0130OC.

84. Karimi K, Sarir H, Mortaz E, et al. Toll-like receptor-4 mediates cigarette smoke-induced cytokine production by human macrophages. Respiratory Research 2006; 7: 66.

85. Zhang S, Petro TM. The effect of nicotine on murine CD4 T cell responses. Int J Immunopharmacol 1996; 18: 467-478.

86. Rival J, Riddle JM, Stein PD. Effects of chronic smoking on platelet function. Thromb Res 1987; 45: 75-85.

87. Fusegawa $\mathrm{Y}$, Goto S, Handa S, Kawada T, Ando Y. Platelet Spontaneous Aggregation in Platelet-Rich Plasma Is Increased in Habitual Smokers. Thrombosis Research 1999; 93: 271-278.

88. Blache D. Involvement of hydrogen and lipid peroxides in acute tobacco smoking-induced platelet hyperactivity. Am J Physiol Heart Circ Physiol 1995; 268: H679-685.

89. Ichiki K, Ikeda H, Haramaki N, Ueno T, Imaizumi T. Long-term Smoking Impairs Platelet-Derived Nitric Oxide Release. Circulation 1996; 94: 3109-3114.

90. Mitsunori S, Yukio K, Fujio N, Mitsuaki I. Smokers Lack Morning Increase in Platelet Sensitivity to Nitric Oxide. Journal of Cardiovascular Pharmacology 2002; 40: 571-576.

91. Shimasaki Y, Saito Y, Yoshimura M, et al. The Effects of Long-term Smoking on Endothelial Nitric Oxide Synthase mRNA Expression in Human Platelets as Detected With Real-time Quantitative RT-PCR. Clinical and Applied Thrombosis/Hemostasis 2007; 13: 43-51.

92. Price JF, Mowbray PI, Lee AJ, Rumley A, Lowe GDO, Fowkes FGR. Relationship between smoking and cardiovascular risk factors in the development of peripheral arterial disease and coronary artery disease; Edinburgh Artery Study: Edinburgh Artery Study. Eur Heart J 1999; 20: 344-353.

93. Weatherley B, Nelson J, Heiss G, et al. The association of the ankle-brachial index with incident coronary heart disease: the Atherosclerosis Risk In Communities (ARIC) study, 1987-2001. BMC Cardiovascular Disorders 2007; 7: 3 .

94. Wattanakit K, Folsom AR, Selvin E, et al. Risk factors for peripheral arterial disease incidence in persons with diabetes: the Atherosclerosis Risk in Communities (ARIC) Study. Atherosclerosis 2005; 180: 389-397.

95. Leng GC, Lee AJ, Fowkes FGR, Lowe GDO, Housley E. The relationship between cigarette smoking and cardiovascular risk factors in peripheral arterial disease compared with ischaemic heart disease: The Edinburgh Artery Study. Eur Heart J 1995; 16: 1542-1548. 
96. Michaud SE, Dussault S, Groleau J, Haddad P, Rivard A. Cigarette smoke exposure impairs VEGF-induced endothelial cell migration: Role of NO and reactive oxygen species. Journal of Molecular and Cellular Cardiology 2006; 41: 275-284.

97. Shin VY, Wu WKK, Chu K-M, et al. Nicotine Induces Cyclooxygenase-2 and Vascular Endothelial Growth Factor Receptor-2 in Association with Tumor-Associated Invasion and Angiogenesis in Gastric Cancer. Mol Cancer Res 2005; 3: 607-615.

98. Magers T, Talbot P, DiCarlantonio G, et al. Cigarette smoke inhalation affects the reproductive system of female hamsters. Reproductive Toxicology 1995; 9: 513-525.

99. Melkonian G, Le C, Zheng W, Talbot P, Martins-Green M. Normal Patterns of Angiogenesis and Extracellular Matrix Deposition in Chick Chorioallantoic Membranes Are Disrupted by Mainstream and Sidestream Cigarette Smoke. Toxicology and Applied Pharmacology 2000; 163: 26-37.

100. Eid HMA, Arnesen H, Hjerkinn EM, Lyberg T, Seljeflot I. Relationship between obesity, smoking, and the endogenous nitric oxide synthase inhibitor, asymmetric dimethylarginine. Metabolism 2004; 53: 1574-1579.
101. Willett WC, Green A, Stampfer MJ, et al. Relative and absolute excess risks of coronary heart disease among women who smoke cigarettes. N Engl J Med 1987; 317: 1303-1309.

102. Negri E, Franzosi MG, La Vecchia C, Santoro L, Nobili A, Tognoni G. Tar yield of cigarettes and risk of acute myocardial infarction. GISSI-EFRIM Investigators. $B M J$ 1993; 306: 1567-1570.

103. Glantz SA, Parmley WW. Passive smoking and heart disease. Epidemiology, physiology, and biochemistry. Circulation 1991; 83: 1-12.

104. Leone A. Relationship Between Cigarette Smoking and Other Coronary Risk Factors in Atherosclerosis: Risk of Cardiovascular Disease and Preventive Measures. Current Pharmaceutical Design 2003; 9: 2417-2423.

105. Hergens MP, Alfredsson L, Bolinder G, Lambe M, Pershagen G, Ye W. Long-term use of Swedish moist snuff and the risk of myocardial infarction amongst men. Journal of Internal Medicine 2007; 262: 351-359.

106. Bolinder G, Alfredsson L, Englund A, de Faire U. Smokeless tobacco use and increased cardiovascular mortality among Swedish construction workers. Am J Public Health 1994; 84: 399-404. 